\title{
AUTODESTRUIÇÃO DO ESCLARECIMENTO OU MODERNIDADE INACABADA
}

Claudio Almir Dalbosco*

SINTTESE - Neste trabalho, a autor expõe o argumento apresentado por Adorno e Horkheimer na Dialética do esclarecimento, considerando decisiva a identificação feita por eles entre esclarecimento e racionalidade instrumental. Em seguida, em forma de excurso, recorre a Kant para demonstrar os limites do argumento daqueles dois autores. Por último, apresenta o argumento de Habermas sobre a racionalidade comunicativa e, a partir dele, busca evidenciar aspectos fundamentais de sua critica a Adorno e Horkheimer. O trabalho assume, como fio condutor, o tema da mo-

\begin{abstract}
In this work, the author exposes the argument presented by Adorno and Horkheimer in Dialektik der Aufklärung utilising the differenciation between enlightenment and instrumental rationality. He also mentions Kant in order to demonstrate the limits of argument of those two authors. Lastly, he presents Habermas' argument about the communicative rationality and tries to make fundamental aspects of his criticism to Adorno and Horkheimer evident. The main plot of this work is modernity.
\end{abstract}

\section{Duas leituras da modernidade}

A Dialética do esclarecimento de Adorno e Horkheimer e o Discurso filosófico da modernidade de Habermas, considerando a diversidade de propósitos e a diferença na estratégia conceitual, são livros que se unem em torno de uma preocupação comum: oferecer um diagnóstico da modernidade cultural. Adorno e Horkheimer, forçando o esclarecimento a iluminar-se a si mesmo, radicalizam sua crítica à modernidade. Habermas, polemizando com os pós-modernos, retorna ao momento de origem da autofundamentação da modernidade que, segundo ele, encontra-se na filosofia hegeliana. Seu intuito é o de resgatar, a partir do próprio discurso filosófico da modernidade, os momentos de racionalidade comunicativa por ela produzida. Habermas, ao contrário de Adorno e Horkheimer e dos pós-modernos, concebe a modernidade como um projeto inacabado.

O confronto de Habermas com Adorno e Horkheimer torna-se instrutivo no sentido de esclarecer problemas relacionados com a tradição cultural da moderni-

* Aluno do Curso de Mestrado da PUCRS e professor do Departamento de Filosofia da Universidade de Passo Fundo.

\begin{tabular}{|l|l|l|l|l|l|}
\hline VERITAS & Porto Alegre & v. 40 & $n^{2} 158$ & Junho 1995 & p. 177-192 \\
\hline
\end{tabular}


dade. O problema, neste confronto, pode ser colocado nos seguintes termos: Qual das duas leituras apresenta melhor consistência no diagnóstico que faz da modernidade? Quais as críticas recíprocas é possivel extrair deste confronto? Que direção cada um destes diagnósticos aponta?

\section{1 - Modernidade e irracionalidade do esclarecimento}

\section{1 - Referências weberianas}

Weber, ao contrário do que pensa Habermas, influenciou os autores da Dialética do esclarecimento muito mais do que Nietzsche. A leitura weberiana da modernidade tem ocupado um lugar de destaque por apresentar peculiaridades em relação a outras leituras, como é o caso das leituras marxista e positivista. Estas particularidades dão conta de aspectos significativos do processo de modernização do Ocidente.

Weber concebe a racionalização como um conceito central para se entender a modernidade. Segundo ele, a modernidade significou um processo intenso de racionalização. Distingue entre uma modernidade cultural e uma modernidade social. A esta última correspondem os subsistemas econômico, administrativo e político. A modernização social provocou um enorme progresso material da sociedade. Com a modernização cultural, tornou-se possível a autonomia de esferas de valores. A Ciência, a Moral e a Arte tornaram-se autônomas. Weber, enquanto pensador inserido na tradição neokantiana, estende para a análise social os diferentes usos da razão pensados por Kant.

A racionalização, enquanto conceito central da modernidade, compõe-se de duas dimensões: Weber indica, de um lado, a existência de uma racionalização formal que se orienta pela racionalidade meio-fim e, de outro, uma racionalização substancial, mais ampla que a formal e que possui como fim a preservação da autonomia da razão. ${ }^{1}$ Da racionalidade formal deriva-se o agir instrumental e estratégico. $^{2}$ Com o conceito de racionalidade substancial Weber quer manter, ainda, a

1 Albrecht WELLMER, "Razón, utopia, y la Dialéctica de la Ilustración", In: J. BERSTEIN. Habermas y la Modemidad, Madrid: Cátedra, 1991, p. 72-73), distingue três aspectos diferentes do conceito de racionalidade de Weber: racionalidade deliberada, formal e discursiva. Diz também que há um sentido mais limitado e outro mais extenso. No sentido limitado a racionalidade significa "um conjunto de tendências inter-relacionadas que operam em niveis diferentes (ou em vários subsistemas) e que indicam uma formalização, instrumentalização e burocratização em aumento de acordo com uma 'lógica' ou necessidade sistemática intema (Ibidem, p. 74). No sentido mais extenso, "a noção de racionalização tem todavia para Weber uma conotação normativa. O conceito de racionalização, tal e como ele o utiliza, está todavia determinado por uma tradiçäo européia na qual ser racional significa uma condição básica e uma tarefa dos seres humanos como seres humanos" (Ibidem, p. 75). Ao que Wellmer chama de sentido limitado, corresponde a racionalidade formal e ao sentido extenso corresponde a racionalidade substancial.

2 Habermas estabelece a conexăo da racionalidade formal com o agir instrumental e estratégico da seguinte forma: "Frente ao conceito de racionalidade formal, Weber havia compreendido as determinações que tomam possiveis a 'calculabilidade' e 'previsibilidade' das ações: frente ao aspecto instrumental, a eficácia dos meios disponíveis, e frente ao aspecto estratégico, a correção na eleição dos meios para preferências, meios e condições mạrginais dadas. Weber chama 'formal' especialmente a este segundo aspecto de racionalidade eletiva, contrapondo-o ao enjuizamento material dos 
potencialidade crítica e reflexiva da razão. Enquanto a racionalização social está na base da modernidade social, a substancial constitui a referência da modernização cultural.

Segundo Wellmer, como também Habermas, há um paradoxo na concepção weberiana de racionalidade que será assumido, posteriormente, por Adorno e Horkheimer na Dialética do esclarecimento. O paradoxo reside no fato de o conceito de racionalidade conter, simultaneamente, a emancipação e a reificação. Ele consiste em que o conceito de racionalização não significa só uma categoria analítica ou descritiva, mas também uma conotação normativa irredutivel. Esste duplo conceito de racionalidade conduzirá Weber à tese do "desencantamento do mundo". ${ }^{3}$ A paradoxalidade do conceito de racionalização se encontra articulada, em Weber, do seguinte modo: "uma vez que as estruturas cognitivas de uma consciência desencantada se institucionalizam como sistemas secularizados do discurso cultural e da interação social, se põem em movimento um processo de racionalização - no sentido agora especificamente weberiano - que tende a sufocar a base social dos indivíduos autônomos e racionais". ${ }^{4}$ Esta paradoxalidade revela que há, implicitamente, uma Filosofia da História profundamente pessimista na teoria weberiana da racionalidade moderna.

\section{2 - A argumentação de Adorno e Horkheimer}

\subsection{1 - Consideração introdutória sobre a dialética do esclarecimento}

A Dialética do esclarecimento reflete a situação catastrófica da sociedade européia dos anos 40 do nosso século. Dubiel, na "Organização científica e experiência política" (Wissenschaftsorganisation und Politische Erfharung), ${ }^{5}$ chama a atenção para três experiências históricas que foram determinantes na formação da teoria crítica e que convergem numa desilusão das expectativas revolucionárias: a evolução, na União Soviética, do socialismo burocrático, a ascensão nazi-fascista na Alemanha e Europa e o desenvolvimento da sociedade de massas nos Estados Unidos. A primeira experiência confirmou o prognóstico weberiano de uma burocratiz̧ação acelerada e a prática stalinista confirmou a crítica de Rosa Luxemburgo à teoria da organização de Lênin. $\mathrm{O}$ fascismo significou a resposta dada pela sociedade capitalista desenvolvida, no período de crise, à possibilidade de uma saída revolucionária. $O$ fascismo demonstrou a capacidade de resposta e de absorção desta sociedade à resistência do movimento operário organizado. A sociedade de

valores que subjazem às preferências subjetivas. Utiliza também este conceito como sinônimo de racionalidade com respeito a fins. Esta se refere à estrutura das orientações de ação que vêm determinadas pela racionalidade cognitivo-instrumental com abstração dos critérios de racionalidade prático-moral ou prático-estético" (J. HABERMAS, Teoria de la acción comunicativa, Vol. I, Madrid: Taurus, 1992, p. 439-40).

3 Conforme utiliza Weber, o termo "desencantamento do mundo", "significa também o núcleo normativo de sua própria postura epistemológica e moral; isto se reflete mais claramente em suas reflexões metodológicas" (WELLMER, op. cit. p. 75).

5 Citado por HABERMAS, op. cit. p. 466-67. 
massas demonstrava, de modo peculiar, a força integradora do capitalismo. Diz Habermas: "A perversão soviética do conteúdo humano do socialismo revolucionário, o fracasso do movimento operário revolucionário em todas as sociedades industriais e a capacidade de integração social que demonstra ter a racionalização quando penetra no âmbito da reprodução cultural - eram as experiências básicas das quais Horkheimer e Adorno trataram de dar razão a princípios dos anos 40". 6

Estas experiências históricas de uma modernidade tardia, experimentadas por Adorno e Horkheimer, agudizam sua atitude de suspeita e sua posição de distância em relação a uma fé exagerada nas potencialidades da razão. Influenciando decisivamente na estrutura argumentativa da Dialética do esclarecimento, estas experiências demarcam a auto-ultrapassagem que os autores vêem-se obrigados a operar do modelo de crítica da ideologia à crítica total da razão. ${ }^{7}$ De outra parte, do ponto de vista interno da teoria crítica, o abandono da crítica da ideologia em nome da crítica total da razão deve-se ao fracasso e inconsistência da Filosofia da História marxiana e de seu pressuposto básico, a saber, a dialética entre as forças produtivas e as relações sociais de produção. No capitalismo tardio, o avanço gigantesco das forças produtivas não provocou uma transformação qualitativa das relações sociais de produção, conforme havia previsto Marx. ${ }^{8}$

Na Dialética do esclarecimento, Adorno e Horkheimer pretendem entender por que a Humanidade em vez de progredir - a fé inabalável no progresso constitui-se na grande apoteose das filosofias da História do século XVIII e do periodo das luzes - retorna cada vez mais a um estado de barbárie. Ao sentido mais amplo e comumente aceito de esclarecimento, como sinônimo de liberdade e de distância dos

6 HABERMAS, op. cit. p. 467.

7 Cf. J. HABERMAS, O discurso filosófico da modernidade, Lisboa: Publicação Dom Quixote, 1990, p. 116-18. O modelo da critica da ideologia é definido por Habermas do seguinte modo: "toma-se critica da ideologia quando pretende demonstrar que a validade da teoria não se dissociou suficientemente do contexto da sua gênese, que por trás da teoria se esconde uma mistura ilicita de poder e validade e que é mesmo a esta que ela ainda por cima deve a sua reputação" (p. 117). O ponto básico da crítica da ideologia reside em demonstrar que em determinada teoria aparecem confundidas questões de sentido com questōes de realidade e que existe esta confusão porque as exigências de validade são determinadas por relações de poder. Através da critica da ideologia o iluminismo se toma critico pela primeira vez. Porém, quando a própria critica da ideologia cai, ela própria, na suspeita de não mais produzir verdade, o iluminismo se toma crítico pela segunda vez. Neste momento, a dúvida se estende também à razão. A Dialética do Iluminismo, segundo Habermas, percorre este caminho: autonomiza a critica mesmo em relação aos seus próprios fundamentos. Autonomizar a crítica em relação aos seus próprios fundamentos constitui aquilo que se denomina o modelo da crítica total da razão.

8 K. MARX, Contribuição à crítica da Economia Politica, São Paulo: Martins Fontes, 1983, p. 24. Marx diz: "Em certo estágio de desenvolvimento, as forças produtivas materiais da sociedade entram em contradição com as relações de produção existentes ou, o que é a sua expressão juridica, com as relações de propriedade no seio das quais se tinha movido até então. De formas de desenvolvimento das forças produtivas estas relaçōes transformam-se no seu entrave. Surge então uma época de revolução social. A transformação da base econômica altera mais ou menos rapidamente toda a imensa superestrutura". A concepçäo marxista ortodoxa transformou esta tese de Marx no elemento central da filosofia marxista da Históna, deduzindo dela a idéia do socialismo como formação social inevitável à sociedade humana. Adomo e Horkheimer, que desde o primeiro instante mantiveram-se no terreno da recepção filosófica da obra de Marx, promovida pela tradição do marxismo ocidental (Lukács, Korsch e Bloch), não poderiam aceitar o fatalismo desta Filosofia da História. Este fator, aliado com as experiências históricas dos anos 40 , provocaram o abandono ou, pelo menos, o distanciamento em relação ao modelo da critica da ideologia. 
homens em relação aos poderes mágicos e míticos, os autores contrapõem um conceito de esclarecimento que ainda está. preso ao mito, refletindo na sua estrutura a estrutura do próprio mito. Neste sentido, entendem o iluminismo como a tentativa fracassada de escapar às potências do destino. A Dialética do esclarecimento significa, portanto, a exposição do reverso, do lado cínico e astuto do processo do iluminismo.

No empenho em tematizar a questão do retorno à barbárie como uma possibilidade sempre presente à sociedade humana, os autores retroagem argumentativamente e oferecem um diagnóstico da tradição cultural ocidental. Entendem que uma investigação que tem como propósito analisar as razões do projeto do esclarecimento precisa retroagir e buscar refletir os problemas no modo através do qual eles se apresentaram na origem da própria constituição da civilização ocidental. Tal investigação precisa dar conta daquele processo no qual o esclarecimento desapropriou o mito de suas funções e da posição de força explicativa, para poder instituir a racionalidade e com ela a constituição da própria subjetividade. $\mathrm{O}$ confronto entre mito e racionalidade, entendido enquanto conflito que esteve na origem do processo da humanização, representou a vitória da razão.

Os autores concebem o conflito entre mito e esclarecimento como algo que permeia toda a tradição da cultura ocidental. Eles entendem por esclarecimento não somente o periodo histórico da "época das luzes". O conceito de esclarecimento é ampliado e entendido como processo histórico universal da Humanidade, caracterizando-se pela postura reflexiva adotada pelo homem no sentido de superar 0 poder da magia e do mito. O esclarecimento simboliza o esforço e a luta desencadeada pelo homem, ao longo da História, para suplantar o mito e construir uma sociedade autônoma e racional. Este esforço radicaliza-se, ou melhor dizendo, tornase claro no sentido de representar o auge da criticidade de tal postura, com o esclarecimento moderno.

\subsection{2 - Os limites do conceito de esclarecimento de Adorno e Horkheimer, segundo a perspectiva kantiana: um excurso}

Embora, como vimos, Adorno e Horkheimer ampliem o conceito de esclarecimento, discutindo-o em seu processo de origem, é o esclarecimento moderno que lhes interessa. Na visão moderna do esclarecimento, Kant ocupa um lugar de destaque. Ele entende por esclarecimento "a saída do homem da sua menoridade de que ele próprio é culpado. A menoridade é a incapacidade de se servir do entendimento sem a orientação de outrem" ${ }^{9}$ O esclarecimento significa a passagem do estado de menoridade ao estado de maioridade. $O$ esclarecimento, no sentido kantiano, representa a coragem de pensar por conta própria, sem estar subordinado aos poderes do mito e da religião: Sapere aude! Tem a coragem de te servires do teu próprio entendimento! Kant, em seu "programa do iluminismo" defende a autonomia da razão. A razão, baseando-se em si mesma, deve estabelecer as condições de possibilidade do conhecimento e da ação.

9 I. KANT, A paz perpétua e outros opúsculos, Lisboa: Edições 70, 1988, p. 11. 
Adorno e Horkheimer, quando se referem ao esclarecimento moderno, destacam o nexo entre racionalidade moderna e racionalidade instrumental. Numa atitude de generalização e nivelamento, concebem a racionalidade da cultura ocidental como um todo, inclusive a kantiana, como racionalidade instrumental. Embora, como veremos em seguida, o alvo da crítica seja o positivismo, os autores, quando se dirigem a Kant, não duvidam em concebê-lo como teórico da racionalidade instrumental.

O retorno a Kant torna-se indispensável num duplo sentido: por um lado, para demonstrar o conceito reduzido e limitado de esclarecimento que sustenta a reflexão de Adorno e Horkheimer; e por outro, para enfocar, a partir de dentro da própria argumentação kantiana, ao contrário do que pensam os autores, possibilidades de crítica à racionalidade instrumental. Por possuirem um conceito extremamente reduzido de esclarecimento, o qual mantêm-se somente no âmbito epistemológico, Adorno e Horkheimer estão impossibilitados de ver na filosofia kantiana, enquanto um momento da racionalidade moderna, elementos de uma racionalidade autônoma.

Na filosofia prática kantiana, especificamente na Fundamentação da Metafísica dos costumes, a segunda formulação do imperativo categórico exige um dever ser de toda a ação humana que deve considerar sempre a Humanidade como fim e nunca como meio; significando isto uma manifestação clara de contraposição à racionalidade instrumental. O imperativo diz: "Age de tal maneira que uses a Humanidade, tanto na sua pessoa como na pessoa de qualquer outro, sempre e simultaneamente como fim e nunca simplesmente como meio". ${ }^{10}$ Ainda no contexto da filosofia prática, outro momento referencial de crítica à racionalidade instrumental é a distinção entre natureza sensivel e natureza supra-sensivel. A natureza sensivel representa a existência de seres racionais mediante leis empiricamente condicionadas e isto significa um estado heterônimo da razão. A natureza supra-sensível, por sua vez, representa a existência dos mesmos seres racionais segundo leis que são independentes de toda a condição empírica, e isto denota a autonomia da razão. A natureza supra-sensivel, diz Kant, "tanto quanto dela podemos fazer um conceito, nada mais é do que uma natureza submetida à autonomia da razão pura prática". ${ }^{11}$

Se é possivel verificar na filosofia prática recursos argumentativos que se opöem ao modelo da racionalidade instrumental, o mesmo ocorre com a filosofia teórica. Entretanto, este projeto de justificativa crítica do esclarecimento moderno, a partir da filosofia teórica, a qual impede de reduzi-lo somente à racionalidade meio-fim, exige uma interpretação da Crítica da razão pura que a considere não só como uma obra de teoria do conhecimento. A Crítica da razão pura deve ser vista como um esforço empreendido por Kant no sentido de estabelecer parâmetros para uma autocrítica da razão. A "Dialética transcendental", nesta perspectiva, torna-se mais importante que a "Analítica transcendental", porque é nela que Kant busca disciplinar a razão quando esta extrapola os limites da experiência. O uso da razão não se esgota em sua relação com a experiência de objetos. A razão se aventura para além da experiência possivel, surgindo neste dominio, aporias (antinomias)

10 I. KANT, Fundamentação da Metafísica dos costumes, Lisboa: Edições 70, 1988, p. 69.

11 I. KANT, Crítica da razão prática, Lisboa: Edições 70, 1989, p. 56. 
que o âmbito da experiência torna-se demasiadamente estreito para servir como referência. Kant admite, deste modo, um uso da razão para além da referência com objetos e propõe-se, na Dialética transcendental, estabelecer "uma crítica do entendimento e da razão no tocante ao seu uso hiperfísico...". ${ }^{12}$

As bases filosóficas de Adorno e Horkheimer, profundamente influenciadas pela tradição hegeliano-marxista, não permitem vislumbrar a possibilidade da própria estrutura argumentativa kantiana significar um núcleo crítico do esclarecimento moderno. Adorno e Horkheimer assimilam, por influência, principalmente, do livro História e consciência de classe de Lukács, a crítica hegeliana a Kant. A recepção lukacsiana desta crítica está fundamentada pela própria crítica marxiana a $\mathrm{He}$ gel. ${ }^{13}$ Ao colocarem-se no interior da tradição hegeliano-marxista, Adorno e Horkheimer distanciam-se e não podem assumir teses centrais da filosofia kantiana, como, por exemplo: a distinção entre noumeno e fenômeno, a distinção entre diferentes usos da razão (prático e teórico), bem como a própria idéia de uma filosofia transcendental que, através de um sujeito transcendental, garante o conhecimento a priori.

Os pressupostos da filosofia kantiana são, portanto, rejeitados em nome da tradição hegeliano-marxista: a) contrariamente à idéia de uma razão transcendental, opõe-se a idéia hegeliana de uma racionalidade que se objetiva através da relação dos homens entre si e com a Natureza; b) em oposição a uma razão cindida em seus diferentes usos, o conceito hegeliano de totalidade assegura a unidade da razão. Na Ciência da Lógica, Hegel funda a unidade entre razão prática e razão teórica. Tal unidade dá-se pela atividade do conceito, sendo o espírito absoluto o ponto de confluência desta unidade. De outra parte, na tradição marxista, Lukács (como Marx) busca fundar a unidade na práxis histórica.

Antes de concluir este tópico, é preciso fazer uma observação sobre a posição de Adorno e Horkheimer; nos anos 40, em relação a Hegel e ao marxismo. No contexto argumentativo da Dialética do esclarecimento, os autores, desacreditados em relação a práxis histórica - o proletariado não significava mais para eles, como significava para Lukács, a possibilidade do esclarecimento tornar-se esclarecido - oscilam entre uma rejeição à unidade da razão e um retorno, ainda que muito tímido, à atividade emancipadora do conceito. Esta oscilação se esclarece, no caso de Adorno, na Mínima Morália e, mais tarde, na Dialética negativa. Na Mínima Morália, em nítida oposição à filosofia de espírito sistemático de Hegel, Adorno afirma, no final do aforismo 29, que "o todo é o não verdadeiro". Na Dialética negativa, em oposição ao trabalho de síntese que o conceito opera no método hegeliano, o autor tende a enfatizar o conceito de negação determinada como o verdadeiro espírito de qualquer pensamento crítico. Pois, o poder de síntese iguala-se ao pensamento identificante, o qual é sinônimo de dominação. Enfim, Adorno e Horkheimer, para se manterem fiéis ao modelo de crítica total da razão assumido, são obrigados a renunciarem aos seus próprios pressupostos.

12 I. KANT, Crítica da razão pura, São Paulo: Abril Cultural, 1980, B 88, (Coleção os Pensadores). 


\subsection{3 - Modernidade e irracionalidade do esclarecimento}

No item anterior, recorrendo à filosofia kantiana, procuramos demonstrar, em poucas palavras, que a própria estratégia conceitual kantiana, quando vista de outro ângulo, já pode significar, ela mesma, uma crítica à dimensão instrumental do esclarecimento moderno. Agora, no momento final desta primeira parte do trabalho, pretendemos apresentar, de modo mais sistemático possível, a estratégia argumentativa de Adorno e Horkheimer no que diz respeito a sua crítica à racionalidade instrumental. Simultaneamente, a exposição concentra-se em detectar a imagem da modernidade que a reflexão dos autores apresenta.

Descrentes em relação ao modelo da crítica da ideologia, os autores buscam respaldar suas análises em outros horizontes conceituais. O confronto entre mito e esclarecimento torna-se, como vimos, um modelo paradigmático no sentido de expor a trajetória da sociedade humana. Os conceitos de mito e esclarecimento são elevados à condição de categorias explicativas universais. Concebem a mito como a forma originária da relação do homem com a Natureza, com os outros homens e consigo mesmo. Concebem como características da estrutura do mito a repetição, a ambigüidade da volta às origens e a pretensão de edificar uma relação não rompida do homem com a Natureza, o ritual e, especificamente, o ritual do sacrifício e a idéia do destino. Também fazem parte, enquanto elementos da estrutura do mito, a narrativa, a explicação e a fixação. Adorno e Horkheimer concebem, de outra parte, o esclarecimento (a racionalidade) como aquela postura reflexiva através da qual o homem, para poder construir sua identidade e fortalecer seu eu, precisa rechaçar e destruir o mito.

A Dialética do esclarecimento traduz-se numa dialética entre mito e racionalidade. Esta dialética vislumbrada pelos autores autoriza-os a conceber que o mito em sua origem já era esclarecimento e este, ao ter-se transformado num pensamento extremamente esclarecido, retorna a uma nova mitologia. Baseando-se na idéia de que há elementos comuns na estrutura do mito e do esclarecimento, os autores estabelecem a identidade, a continuidade e o retorno entre um e outro. Assim, um mito que narra, explica e fixa já apresenta características do esclarecimento. ${ }^{14}$ Por outro lado, o esclarecimento, ao tornar-se esclarecido, retorna a uma nova mitologia, isto porque combate o mito com o próprio princípio daquele: "o princípio da imanência, a explicação de todo o acontecimento como repetição, que o esclarecimento defende contra a imaginação mítica, é o princípio do próprio mito". ${ }^{15}$

A análise da dialética entre mito e esclarecimento dá-se a partir de dois momentos históricos distintos: o período homérico, no qual, a Odisséia de Homero constitui a referência e o período moderno (contemporâneo) onde a figura do positivismo conduz à análise. A dialética entre mito e esclarecimento, tematizada a par-

14. Dizem os autores que na forma como nos mitos foram encontrados pelos poetas trágicos já assumiam "o signo daquela disciplina e poder que Bacon enaltece como o objetivo a se alcançar" (T. ADORNO e M. HORKHEIMER, Dialética do esclarecimento, Rio de Janeiro: Jorge Zahar Editor, 1986, p. 23).

15 Em outra passagem afirmam: "Do mesmo modo que os mitos já levam a cabo o esclarecimento, assim o esclarecimento fica cada vez mais enredado, a cada passo que dá, na mitologia. Todo o conteúdo, ele o recebe dos mitos, para destrui-los e ao julgá-los, ele cai na órbita do mito" (Ibidem, p. 26). 
tir destes dois momentos, revela uma tese comum a ambos: a racionalidade - que já estava presente no mito e que definirá o esclarecimento - é uma racionalidade de tipo instrumental.

Voltemos agora a nossa análise, de modo mais específico, para o tema da modernidade. A própria estrutura do livro Dialética do esclarecimento configura a imagem, o que faz eco à herança weberiana, da autonomização das esferas de valores produzidas pela modernidade. O livro compõe-se de um ensaio, dois excursos e três apêndices. No ensaio "o conceito do esclarecimento", a discussão concentrase sobre a ciência; no segundo excurso, com o título "Juliete ou esclarecimento e Moral", o foco da atenção recai sobre a Moral. E no apêndice "A indústria cultural", a reflexão trata da Arte. Comparativamente, pode-se estabelecer o seguinte quadro entre a concepção weberiana da modernidade cultural e a estrutura da Dialética do esclarecimento:

\begin{tabular}{|l|l|}
\hline \multicolumn{1}{|c|}{ MAX WEBER } & DIALÉTICA DO ESCLARECIMENTO \\
\hline Modernidade & Modernidade \\
\hline Autonomia das esferas de valor: & \multicolumn{1}{|c|}{ Razão Moderna } \\
a) Ciência & a) Conceito de Iluminismo: Ciência moderna \\
b) Moral & b) Iluminismo e Moral: Moral moderna \\
c) Arte & c) Indústria Cultural: Arte autônoma \\
\hline
\end{tabular}

O juizo emitido pelos autores sobre as três esferas consiste em concebê-las como dominadas pela racionalidade instrumental: o ideal de objetividade da Ciência reduz-se ao cálculo e à mensurabilidade; a Moral curva-se diante da única moral possivel, a Ciência; e a Arte, transformada em mercadoria, representa a realização da racionalidade instrumental no plano da cultura: a mercantilização da Arte é indício da mercantilização da cultura como um todo. A razão, segundo Adorno e Horkheimer, em seus produtos modernos, a Ciência, a Moral e a Arte, está submetida aos ditames da racionalidade instrumental.

Por questões de natureza do próprio trabalho, não podemos tratar das esferas da Moral e Estética. Concentramos nossa análise na esfera da Ciência, relacionando-a com o problema da racionalidade instrumental. A partir da análise da Ciência, os autores têm como propósito descortinar a base epistêmica que sustenta a racionalidade do esclarecimento moderno. No estudo intitulado "O conceito de esclarecimento", a análise concentra-se sabre o conceito epistemológico de esclarecimento. Pode-se dizer, inclusive, que no conceito de esclarecimento de Adorno e Horkheimer só há lugar para a epistemologia. Deste modo, embora estejam presentes, na Dialética do esclarecimento, as três esferas de valor autonomizadas pela modernidade, todas elas são reduzidas à esfera epistemológica e esta, à racionalidade instrumental.

Este procedimento explica-se pela própria estratégia argumentativa adotada pelos autores. Procedem identificando o esclarecimento com o saber, o saber com a ciência moderna e esta com o positivismo. Na base da ciência moderna, que é positivista, está a racionalidade instrumental, a qual significa a supressão da reflexão 
em nome do procedimento metodológico. O procedimento metodológico elimina a reflexão por estar baseado no cálculo, no número, na lógica da identidade, enfim por estar baseado no modelo físico-matemático. No esclarecimento moderno, na medida em que a racionalidade instrumental universaliza-se e se transforma na única racionalidade possivel, a teoria reflexiva cede lugar ao pensamento ordenador e calculador de probabilidades. $\mathrm{O}$ dominio da racionalidade instrumental sobre o esclarecimento moderno representa a transformação do número em cânon do próprio esclarecimento.

Resumindo, duas idéias são centrais na estratégia argumentativa dos autores: a) a dialética entre mito e esclarecimento e a identificação de elementos comuns na estrutura de ambos; b) o conceito epistemológico de esclarecimento e a redução do mesmo à racionalidade instrumental. Destas idéias, Adorno e Horkheimer extraem algumas conclusões: 1) A humanização, a produção da cultura e o progresso ocorreram às custas do aumento da dominação da natureza externa e da repressão da natureza interna. 2) $O$ esclarecimento moderno não representou significativamente maior liberdade ao homem: quanto mais o homem pensou ter-se distanciado do mito, mais dentro dele se encontrou. 3) Por último, o mundo moderno, portanto, um mundo totalmente racionalizado, só aparentemente está desencantado.

\section{2 - Modernidade inacabada}

Na parte final deste trabalho, faremos algumas considerações sobre o conceito de racionalidade comunicativa e, em seguida, exporemos aspectos considerados centrais da crítica habermasiana a Adorno e Horkheimer.

\section{1 - A racionalidade comunicativa}

Com a teoria da ação comunicativa, fundamentada por uma teoria da racionalidade, Habermas propõe-se oferecer os fundamentos normativos de uma teoria crítica da sociedade, os quais, segundo ele, estavam ausentes nas elaborações teóricas dos pensadores da primeira geração da teoria crítica. Com ela, Habermas pretende retomar o projeto original da teoria crítica dos anos 30 . Porém, como ele mesmo adverte, trata-se de um "regresso sem ter que pagar o tributo ao transfundo histórico-filosófico da teoria crítica". ${ }^{16}$

Tanto a teoria da racionalidade como a teoria da ação comunicativa são tributárias da guinada lingüística. Já no período final da década de 60, Habermas está convencido de que um projeto de fundamentação de uma teoria crítica precisa ser deslocado do interior do paradigma da consciência para o paradigma da linguagem. Nos anos 70, entrando em contato com a literatura da filosofia analítica, empreende o esforço de deslocamento de paradigma. O resultado destes esforços culminará em 1981 com a publicação da Teoria da ação comunicativa. Nela se encontram mesclados, além, evidentemente, da teoria da ação comunicativa, uma teoria da racionalidade e uma teoria da modernidade. Na teoria da ação comunicativa passam-se em revista grandes tradições teóricas (filosóficas e sociológicas) da mo-

16 J. HABERMAS, Ensayos Politicos, Barcelona: Edições Peninsula, 1988, p. 154. 
dernidade. Neste estudo encontra-se, de modo sistemático, uma crítica à primeira geração de pensadores da teoria critica, sobretudo Adorno e Horkheimer.

A teoria da racionalidade habermasiana quer dispor, a um só tempo, de um conceito amplo e modesto de razão. Amplo no sentido de que o conceito de razão, devidamente ampliado, extrapola o âmbito da subjetividade, para assumir como pressuposto a intersubjetividade. O conceito modesto de razão coloca-se como uma exigência à Filosofia, tendo em vista que esta só conseguirá dialogar produtivamente com as ciências na medida em que assumir uma posição mais humilde e menos pretenciosa. Neste sentido, a Filosofia precisa revisar o seu conceito clássico de prima philosophia. O conceito amplo e modesto de razão é pensado a partir de uma dupla perspectiva: a partir do desenvolvimento das ciências e a partir da insuficiência do paradigma da filosofia da consciência. Quando reflete sobre a insuficiência do paradigma da filosofia da consciência, Habermas enfrenta-se com os principais representantes deste paradigma, de modo especial com Kant. No confronto com Kant, ${ }^{17}$ Habermas insere-se na recepção que a filosofia analítica anglosaxônica, principalmente Strawson, faz da filosofia kantiana. O resultado desta recepção aponta para um conceito enfraquecido de a priori e transcendental, culminando com a substituição da filosofia transcendental kantiana pela idéia de uma ciência reconstrutiva. Com a função do conceito de reconstrução racional e com ele a idéia de uma ciência reconstrutiva, Habermas pensa estar livre do conceito forte de razão e pensa também poder distanciar-se das aporias e limites da filosofia da consciência.

O confronto de Habermas com Kant é fundamental, do ponto de vista filosófico, para esclarecer a passagem do conceito transcendental ao conceito procedi-

17 Pela natureza do trabalho não podemos nos estender no confronto Kant-Habermas. Consideramos, no entanto, este confronto fundamental no sentido de refletir a dimensäo propriamente filosófica do pensamento de Habermas. Também ele é decisivo no que diz respeito àquela tentativa anteriormente feita de criticar Adomo e Horkheimer a partir de um enfoque kantiano. Em outro momento, é preciso resolver a tensão presente neste trabalho entre este esforço em demonstrar a existência, em Kant, de um conceito critico de esclarecimento e a própria crítica habermasiana a Adomo e Horkheimer como prisioneiros do paradigma da filosofia da consciência. A questão pode ser colocada nos seguintes moldes: como uma postura de critica aos frankfurtianos a partir de Kant enfrenta a crítica habermasiana a estes autores, considerando-os presos ao paradigma da consciência? Pensamos, neste sentido, que uma altemativa possivel é a de pôr em questão a própria teoria do paradigma de Habermas e demonstrar a insuficiência da leitura que ela produz sobre a História da Filosofia. De outra parte, a perspectiva de ler Kant com o propósito de criticar Adomo e Horkheimer e o próprio Habermas, precisa enfrentar, entre outras, as seguintes questões: a) o conceito de Ciência em Kant e o problema da relação entre Filosofia e Ciência e b) invalidar a critica habermasiana de que a razão em Kant está limitada ao âmbito subjetivo e monológico. Habermas não assume o conceito a priori de razão no sentido pensado por Kant. Seu desacordo com Kant localiza-se sobre a tese do sujeito transcendental. Em Kant a fundamentação da racionalidade, tanto em seu sentido teórico (a validade objetiva da categoria) como prático (a fundamentação racional e a priori da lei moral) é buscada na estrutura da subjetividade, a qual, em última instância, reside no sujeito transcendental. Habermas, por influência da tradição hegeliana, comparte, em certo sentido, da idéia da razão objetiva. A estrutura da racionalidade deve ser buscada na razão que está encarnada no conhecimento, na fala e na ação. Neste sentido, a distinção entre empirico e transcendental assumido por Habermas é diferente da distinção estabelecida por Kant. A alternativa coloca-se, aqui, portanto, no seguinte: assumir um retomo a Kant, implicando isso em assumir o conceito "forte" de filosofia transcendental, ou apoiar-se em Habermas e assumir sua posição de enfraquecimento do conceito de transcendental. Qualquer uma das altemativas só pode ser assumida, evidentemente, a partir do trabalho paciencioso de investigaçäo e análise do pensamento de ambos os autores. 
mental e comunicativo de razão. Habermas desenvolve esta passagem ao mesmo tempo em que pretende assegurar a centralidade do conceito de razão à reflexão filosófica. Considera, neste sentido, que a razão sempre foi o tema principal da Filosofia, pois o pensamento filosófico nasce da reflexão da razão encarnada no conhecimento, na fala e nas ações. ${ }^{18}$

Este conceito procedimental e comunicativo de razão fundamenta tanto a teoria da racionalidade como a própria teoria da ação comunicativa. Os fundamentos da teoria da racionalidade são buscados no nexo entre razão e linguagem. Este nexo, por sua vez, revela a importância da guinada lingǘstica: a filosofia analítica assegurou uma nova convicção ao revelar que a racionalidade subjacente à linguagem deveria ser a referência da reflexão filosófica. Habermas, na pragmática universal, considerando o passo dado pela guinada lingüística, vai além e demonstra que não só a linguagem, mas também a fala é suscetivel de análise formal. A concepção habermasiana de uma pragmática universal baseia-se, segundo MacCarthy, "na pretensão de que não só os aspectos fonéticos, sintáticos e semânticos das orações, senão certos aspectos pragmáticos das emissões - isto é, não só a lingua senão também a fala, não só a competência lingüística senão também a competência comunicativa - admitem uma reconstrução racional em termos universais" ${ }^{19}$

Com o projeto da pragmática universal, Habermas pensa ter estabelecido um ponto de referência normativo à sua própria teoria. Isto se esclarece quando ele diz que a referência normativa reside no "potêncial de racionalidade ínsito na base de validez da fala". ${ }^{20} \mathrm{~A}$ base de validez da fala é o objeto de investigação da pragmática universal porque é nela que residem a dimensão intersubjetiva e a possibilidade de um acordo válido (busca do entendimento) enquanto elementos característicos da linguagem humana.

$\mathrm{Na}$ base de validez da fala são identificadas três pretensões de validez: a verdade, a normatividade e a expressividade. Cada uma destas pretensões aponta para uma determinada dimensão da racionalidade comunicativa, implicando numa relação característica do homem consigo mesmo, com os outros homens e com a Natureza. Assim, a verdade objetiva refere-se ao mundo dos fatos e contempla a relação do sujeito cognoscente com o mundo objetivo; a exatidão normativa diz respeito ao mundo social das normas e designa a relação prática do sujeito com o mundo social; por último, a sinceridade subjetiva corresponde ao mundo da experiência interior e trata da relação do sujeito sofrente e apaixonado com sua própria natureza interna, com sua subjetividade e com a subjetividade dos demais.

A racionalidade comunicativa está diretamente vinculada às pretensões de validez, significando um modo de tratar os requisitos de validez. As pretensões de validez expressam um mínimo de racionalidade que falante e ouvinte devem aceitar para poderem iniciar um diálogo. A concepção de racionalidade comunicativa expressa, segundo Wellmer, ${ }^{21}$ a concepção de racionalidade que "compreende a relação interna entre as pretensões de validez intersubjetiva e o compromisso com

18 J. HABERMAS, Teoría de la Acción Comunicativa, Vol. I, p. 15.

19 T. MacCARTHY, La Teoria Crítica de Jürgen Habermas, Madrid: Tecnos, 1992, p. 317.

20 J. HABERMAS, op. cit. p. 433.

21 A. WELLMER, op. cit. p. 90 
respeito a dar e receber argumentos". O caso típico ou o estado normal da racionalidade comunicativa, segundo pensa Habermas, não é o da interação mediada por um "consenso de fundo", mas sim, interações nas quais o consenso precisa ser fundado ou negociado. Como o pleno acordo entre as pretensões de validez não é o estado normal da ação comunicativa, as próprias pretensões de validez são constantemente questionadas, isto é, problematizadas. A cada uma das pretensões corresponde um tipo de resposta que damos aos problemas seguidos: no âmbito da verdade, respondemos com explicações; no âmbito da retidão normativa valem justificações e no âmbito da veracidade a fala é confrontada com a ação.

A condição de possibilidade das pretensões de validez é, portanto, a condição de que estas precisam constantemente serem explicadas, justificadas e confrontadas com a ação. Esta condição, que é a condição de validade das pretensões de validez, revela a potencialidade racional (reflexiva) da linguagem humana. A racionalidade comunicativa tematiza a partir das pretensões de validez, aponta para "uma concepção (e autoconcepção) de comunicação simbólica que não permite que nenhum requisito de validez fique isento, em princípio, de um possivel exame crítico". ${ }^{22}$ Esta potencialidade reflexiva inerente à fala humana possibilita Habermas conceber a ação comunicativa como um "mecanismo de coordenação da ação" dos indivíduos em sociedade.

Para concluir estas considerações sobre a racionalidade comunicativa é preciso dizer algo sobre a modernidade. No pensamento de Habermas, há uma nítida relação entre a racionalidade comunicativa e a modernidade. As pretensões de validez que estão presentes em qualquer ato de fala referem-se ao próprio conteúdo normativo liberado pela modernidade: a Ciência, a Moral e a Arte. O potêncial comunicativo inerente à racionalidade comunicativa, isto é, presente nas pretensões de validez subjacentes aos atos de fala, só se tornou possível à ação comunicativa na medida em que se destruiu o dogmatismo implícito às concepções tradicionais. Simultaneamente, as pretensões de validez assumem a condição de serem possiveis somente por meio de argumentos, isto é, por justificação racional. A modernidade, ao liberar esferas de valores, tornando a Ciência, a Moral e a Arte esferas autônomas, põe em questão o conteúdo das concepções tradicionais de mundo. $O$ saldo positivo da liberação do conteúdo normativo da modernidade em relação às concepções tradicionais consiste no fato de a argumentação, enquanto meio de restabelecer o acordo intersubjetivo, assumir um papel central. A racionalidade comunicativa ocorre, segundo Habermas, ali onde as formas de ação comunicativa e de argumentação substituem outros mecanismos de coordenação da ação, de integração social ou de reprodução simbólica.

22 Ibidem, p. 91. 


\section{2 - Modernidade inacabada ou racionalidade instrumental: a crítica habermasiana a Adorno e Horkheimer}

Numa entrevista concedida a Honneth e outros, ${ }^{23}$ Habermas reconhece que durante os anos de estudante, sem saber da existência da teoria crítica, havia percorrido uma trajetória intelectual semelhante à de Adorno e Horkheimer. Leu Lukács e contemplou o contexto do debate sobre Kant e o "idealismo objetivo" configurado pelos jovens hegelianos. A sua leitura de Adorno - mais tarde (1956) Habermas mantém um contato direto com ele, tornando-se seu assistente - impulsionouo "a recolher de modo sistemático o que Lukács e Korsch representavam historicamente: a teoria da reificação entendida como uma teoria da racionalização". Neste momento, então, o que lhe interessava era "uma teoria da modernidade, uma teoria da patologia da modernidade desde o ponto de vista da realização deformante da razão na história". ${ }^{24}$

Nesta mesma entrevista, Habermas expõe os pontos considerados débeis da teoria crítica representada pela figura dos primeiros pensadores do Instituto de Investigação Social. Considera que a teoria crítica de Adorno e Horkheimer, sobretudo aquela teoria que começa a se desenhar a partir dos anos 40 , apresenta três pontos deficitários: ausência de "fundamentos normativos", deficiência de um "conceito de verdade e sua relação com as ciências" e uma "infravalorização das tradições do Estado democrático de direito".

O problema dos fundamentos normativos está relacionado ao fato de que a teoria critica, em sua forma mais conseqüente, não pode referir-se a uma forma qualquer de análise empírica ou discursiva das circunstâncias sociais. $\mathrm{O}$ limite normativo da teoria dos anos 40 está relacionada com o modelo teórico da crítica total da razão assumido pelos autores: ao autonomizarem a crítica em relação aos seus próprios fundamentos, eles impossibilitam a construção de referenciais normativos. $^{25}$

O segundo déficit, o conceito de verdade e sua relação com as ciências, está relacionado com o conceito filosófico de verdade que os velhos frankfurtianos recolhem de Hegel. Este conceito é irreconciliável com a falibilidade do trabalho científico. Isto é, Adorno e Horkheimer não desenvolvem um conceito de verdade que seja capaz de assegurar uma relação produtiva entre Filosofia e Ciência. O conceito por eles assumido torna incompativel tal relação.

Por último, o déficit em relação às idéias e valores gerados pelas instituições do Estado burguês. Segundo Habermas, a autodesqualificação da razão foi intensa, desde a perspectiva da Dialética do esclarecimento, que Adorno e Horkheimer concebem as instituições políticas, sociais e a práxis da vida cotidiana como completamente vazias de qualquer vestígio de razão. Para contrapor-se a esta perspectiva, Habermas recorre a Marx e diz que, a partir de uma interpretação correta de seu

23 Esta entrevista encontra-se publicada em J. HABERMAS, Ensayos Políticos, Barcelona: Edições Península, 1988, p. 137-76. Além de.Honnet, participaram Knödler-Bunte e Widmann.

24 Neste sentido, Adorno e Horkeimer abandona o próprio conceito histório-filosófico de razão que estava na base da teoria critica dos anos 30 .

25 Neste sentido, Adorno e Horkheimer abandonam o próprio conceito histórico-filosófico de razão que estava na base da teoria crítica dos anos 30 . 
pensamento, já se pode ver "que nas instituições do Estado burguês estão incorporadas idéias que pertencem a uma tradição que merece a pena preservar em uma sociedade socialista". ${ }^{26}$

O diagnóstico habermasiano da modernidade aponta para uma direção contrária de Adorno e Horkheimer. A distância entre ele e os teóricos frankfurtianos se esclarece a partir da direção que aqueles assumem na Dialética do esclarecimento. Com a Dialética do esclarecimento, Adorno e Horkheimer "perderam definitivamente a sua confiança na dinâmica revolucionária das forças produtivas e no impacto do pensamento negativo. Tanto as forças produtivas como o pensamento crítico eram considerados frente à perspectiva de sua fusão com seu contrário, com as forças de dominação". ${ }^{27}$ Habermas opõe-se de modo decisivo ao modelo de crítica total da razão assumido pelos autores.

No livro O discurso filosófico da modernidade, Habermas diz que uma leitura atenta da Dialética do esclarecimento revela: a) que a tese que neste livro está em causa não é menos arriscada do que o diagnóstico do niilismo estabelecido de forma semelhante por Nietzsche; b) que os autores, conscientes deste risco, fazem uma tentativa conseqüente de fundamentar a sua crítica da cultura; c) que ao fazêlo, porém, aceitam abstrações e nivelamentos que põem em questão a credibilidade do que levam a cabo. ${ }^{23} \mathrm{~A}$ crítica que Habermas desenvolve aos autores, neste livro, pode ser resumido em três aspectos: a) Adorno e Horkheimer assumem uma atitude de nivelamento e abstração; b) Adorno e Horkheimer não se preocupam com teoria das ciências; c) por último, a Dialética do esclarecimento não faz justiça ao conteúdo racional da modernidade cultural que se fixou nos ideais burgueses. Detemo-nos, aqui, ao terceiro aspecto da crítica, por estar ele relacionado, de modo mais direto, com o tema da modernidade.

Adorno e Horkheimer, como vimos, partem da tese de que a própria razão destrói a Humanidade que ela mesma possibilitou. Esta tese sustenta-se, no primeiro excurso, pela idéia de que o processo do esclarecimento se deve, desde os seus primórdios, ao impulso de autopreservação que mutila a razão porque só a reclama como razão instrumental. Com a Dialética do esclarecimento, eles visam comprovar que a razão, em seus produtos mais tardios (a Ciência, a Moral e a Arte) permanece submetida aos ditames da racionalidade orientada para fins. A ciência moderna, ao transformar-se em positivismo, abandona toda a pretensão de conhecimento. Com a dissolução das imagens religioso-metafísicas do mundo, todos os padrões normativos perdem o seu crédito ante toda a autoridade da Ciência. A Arte, fundida com o entretenimento, é paralisada na sua força inovadora e esvaziada de todos os seus conteúdos críticos e utópicos. A argumentação que os autores desenvolvem sobre a Ciência, a Moral e Arte seguem a mesma figura: "a separação dos domínios culturais, a decadência da razão substancial ainda corporificada na Religião e na Metafísica, desvitaliza a tal ponto os momentos racionais isolados de-

26 J. HABERMAS, op. cit., p. 146.

27 J. HABERMAS, "La Psique 'Al Terminador' y el renacimiento de la subjetividad rebelde", in R. J. BERNSTEIN (org.), Habermas y la modernidad, p. 120.

28 J. HABERMAS, O discurso filosófico da modemidade, p. 113. 
sapossados da sua coerência, que estes regridem convertendo-se em racionalidade ao serviço da autopreservação tornada selvagem". ${ }^{29}$

A posição de Habermas consiste em demonstrar que a crítica da razão instrumental, reduzida a este núcleo, nivela de forma surpreendente a imagem da modernidade. Os autores não reconhecem, como conquista da modernidade cultural, a diferenciação das esferas de valor. Para Habermas, porém, a força de negação e a capacidade de diferenciar entre sim e não, ao contrário do que pensam Adorno e Horkheimer, não é tolhida, antes potenciada. O conceito crítico de razão liberado pela modernidade cultural não é reconhecido por Adorno e Horkheimer e eles não podem reconhecê-lo devido a seus próprios pressupostos argumentativos.

Embora ocorra, na economia capitalista e no Estado moderno, a tendência de confinar as questões de validade ao horizonte limitado da razão instrumental, de outra parte, pensa Habermas, que no âmbito da modernidade cultural verifica-se uma progressiva diferenciação de uma razão que assume uma forma processual. A Dialética do esclarecimento não faz justiça ao conteúdo racional da modernidade cultural que se fixou nos ideais burgueses. Exemplos deste conteúdo racional são: a) a dinâmica teórica própria que leva as ciências e mesmo a auto-reflexão das ciências sempre para lá da produção de um saber tecnicamente aproveitável; b) os alicerces universalistas da Moral e do Direito; c) a produtividade e a força explosiva das experiências estéticas fundamentais.

Sobretudo, por não fazer justiça ao potencial de racionalidade crítica produzido pela modernidade, a Dialética do esclarecimento deixa a impressão de incompletude e unilateralidade. Para Habermas, "o leitor tem razão em sentir que a apresentação niveladora não leva em consideração traços essenciais da modernidade cultural" ${ }^{30}$ Baseando-se neste caráter incompleto e unilateral da obra, Habermas formula a tese de que os autores situam tão fundo o ponto de partida da sua crítica do esclarecimento que "a Dialética do esclarecimento dificilmente abre qualquer perspectiva de escapar ao mito da racionalidade orientada para fins tornada força objetiva".

Por fim, poder-se-ia recorrer à estratégia conceitual de Adorno e Horkheimer e, a partir do seu interior, fazer a objeção a Habermas de que no contexto argumentativo da Dialética do esclarecimento, encontram-se possibilidades de emancipação. A obra de arte autêntica, o trabalho do conceito, a idéia da negação determinada e a exigência clássica do pensamento pensar-se a si mesmo significam diferentes figuras e momentos através dos quais a modernidade pode, ainda, esclarecer-se a si mesma. Portanto, estes elementos poderiam tornar problemática a interpretação de Habermas. Ele, porém, recorrendo a Apel, contra-argumentaria dizendo que Adorno e Horkheimer, ao radicalizarem sua leitura da modernidade, orientando-se pelos moldes de uma crítica total da razão, caem numa contradição performativa: negam a razão recorrendo a pressuposições argumentativas.

29 Ibidem, p. 114.

30 Ibidem, p. 115. 